\title{
PERLINDUNGAN INDIKASI GEOGRAFIS UNTUK MELINDUNGI PRODUK-PRODUK MASYARAKAT LOKAL
}

\author{
Nurohma \\ Widyaiswara Madya BPSDM Hukum dan HAM, Indonesia. \\ Email : kangnuro@gmail.com
}

\begin{abstract}
Abstrak
Penelitian ini bertujuan untuk menganalisis mengenai perlindungan terhadap Indikasi Geografis berdasarkan Peraturan Pemerintah Nomor 51 Tahun 2007 untuk melindungi produk-produk masyarakat lokal. Metode penelitian yang digunakan adalah normatif dengan menggunakan pendekatan peraturan perundang-undangan dan pendekatan konseptual. Sejak di undangkan Peraturan Pemerintah Nomor 51 Tahun 2007 tentang Indikasi Geografis pada September 2007, merupakan titik awal perlindungan Indikasi Geografis di Indonesia atas produk-produk masyarakat lokal. Produk-produk masyarakat lokal yang bersifat kederahan di wilayahnya nyata memperlihatkan tingkat perekonomian seperti beberapa produk-produk yang telah ada antara lain; Kopi Kintamani, Kopi Arabika Toraya, Lada Bangka, Markisa Medan, Kangkung Lombok, Vanili Kepulauan Alor Cengkeh, Pala Ternate, Minyak Kayu Putih Ambon, Kayu Manis Bukit Tinggi, Tembakau Hitam Sumedang, Kopi Arabika Gayo,Susu Kuda Sumbawa, Cengkeh Minahasa, Ubi Celembu dan masih banyak lainnya. Produk-produk ini akan dapat memberikan kesukseskan dalam perekonomian asal saja masyarakat yang memilikinya mendaftarkan dengan sistem pendaftaran indikasi geografis yang selanjutnya dapat mengembangkannya ke negara-negara luar.
\end{abstract}

Kata Kunci: Perlindungan Hukum; Indikasi Geografis; Produk Lokal.

\begin{abstract}
This study aims to analyze the protection against Geographical Indications based on Government Regulation No. 51 of 2007 to protect local people's products. The research method used is normative by using a statutory approach and a conceptual approach. Since the enactment of Government Regulation Number 51 of 2007 concerning Geographical Indications in September 2007, it is the starting point for the protection of Geographical Indications in Indonesia for the products of local communities. Local people's products that are regional in nature clearly show the level of the economy, such as several existing products, among others; Kintamani Coffee, Toraya Arabica Coffee, Bangka Pepper, Medan Passion Fruit, Lombok Kangkung, Vanilla Alor Cloves, Ternate Nutmeg, Ambon Eucalyptus Oil, Bukit Tinggi Cinnamon, Sumedang Black Tobacco, Gayo Arabica Coffee, Sumbawa Horse Milk, Minahasa Cloves, Sweet Potatoes Celembu and many others. These products will be able to provide success in the economy as long as the people who have them register with the geographical indication registration system which can then develop them to foreign countries.
\end{abstract}

Keywords: Legal Protection; Geographical Indication; Local Products.

\section{A. PENDAHULUAN}

Aline keempat Pembukaan Undang-Undang Dasar 1945 (UUD 1945) merumuskan tujuan negara sebagai berikut: "... Kemudian daripada itu untuk membentuk suatu Pemerintahan Negara Indonesia yang melindungi segenap bangsa Indonesia dan seluruh tumpah darah Indonesia dan untuk memajukan kesejahteraan umum, mencerdaskan kehidupan bangsa, dan ikut melaksanakan ketertiban dunia yang berdasarkan kemerdekaan, perdamaian abadi

110 Nurohma | Perlindungan Indikasi Geografis Berdasarkan Peraturan Pemerintah ... 
dan keadilan sosial..., yang kemudian dituangkan dalam pasal-pasal UUD 1945, yang salah satu aspeknya menggambarkan kesejahteraan suatu bangsa atas keberhasilannya dalam pembangunan ekonomi. Dalam pasal 33 UUD 1945 menyebutkan :

1. Perekonomian disusun sebagai usaha bersama berdasarkan asas kekeluargaan.

2. Cabang-cabang produksi yang penting bagi negara dan yang menguasai hayat hidup orang banyak dikuasai oleh negara.

3. Bumi dan air dan kekayaan alam yang terkandung didalamnya dikuasai oleh negara dan dipergunakan untuk sebesar-besarnya kemakmuran rakyat.

4. Perekonomian nasional diselenggarakan berdasarkan atas demokrasi ekonomi dengan prinsip kedilan, kebersamaan, efisiensi, berkelanjutan, berwawasan lingkungan, kemandirian, serta dengan menjaga keseimbangan kemajuan dan kesatuan ekonomi nasional.

Lebih lanjut lagi dalam konsideran ketetapan MPR. No.IX/MPR/2001 menyatakan bahwa : Sumber daya alam/sumber daya agraris meliputi bumi, air, ruang angkasa dan kekayaan alam yang terkandung didalamnya sebagai rahmat Tuhan Yang Maha Esa kepada bangsa Indonesia, merupakan kekayaan nasional yang wajib disyukuri. Oleh karena itu harus dikelola dan dimanfaatkan secara optimal bagi generasi sekarang dan generasi mendatang dalam rangka mewujudkan masyarakat adil dan makmur.

Dasar dari ketentuan-ketentuan diatas merupakan kaidah fundamental hukum HKI sebagai landasan merumuskan konsep negara yang menyelenggarakan kesejahteraan bagi masyarakat atas pengelolaan sumber daya alam milik bangsa Indonesia, karena dalam praktek beberapa waktu yang lalu banyak kekayaan intelektual milik masyarakat dan bangsa Indonesia diambil dan dimanfaatkan oleh pihak luar dan memberikan keuntungan ekonomi bagi negaranya, sehigga pemerintah Indonesia perlu mempunyai suatu konsepsi bahwa hak kekayaan intelektual milik bangsa Indonesia dapat memberikan kesejahteraan bagi masyarakat.

Sebagai negara kepulauan yang memiliki pengetahuan, tradisi dan budaya dan trpis yang menghasilkan berbagai macam barang/produk yang mempunyai potensi ekonomi yang tinggi sudah seharusnya mempunyai suatu konsep perlindungan hukum atas barang/produk yang ada sehingga dengan nilai ekonomi yang ada dapat mewujudkankesejahteraan bagi rakyatnya.

Permasalahan yang terjadi di bidang HKI dibeberapa negara termasuk Indonesia, sangat menginginkan perlindungan hukum atas HKI, hal mana terkait dengan adanya HKI bangsa Indonesia berupa makanan khas seperti; tempe, kopi, rendang, kemudian keseniannya yaitu tarian, bahkan batikpun ikut dimanfaatkan oleh negara luar, walaupun disatu sisi terlihat pula bangsa Indonesia juga melakukan hal yang sama untuk negara luar seperti pembajakan atas CD, dan VCD.

Perlindungan dimaksud agar pemilik HKI baik perorangan, kelompok atau badan usaha dapat menggunakan haknya atau mengeksplorasi kekayaannya dengan aman yang pada gilirannya dapat menciptakan iklim ekonomi dari hasil yang dikaryakannya dan dapat menciptakan iklim ekonomi juga bagi negara sehingga dapat memberikan manfaat dan kesejahteraan bagi bangsanya karena adanya perlindungan. Perlindungan dalam hal ini manakala pemeritah turut serta melakukan inplementasi bagi masyarakat termasuk instansi-instansi dan perguruan tinggi yang berada diseluruh Indonesia yang menangani bidang HKI.

Memberikan perlindungan atas Kekayaan Intelektual kepada masyarakat merupakan suatu konsep dari rechtstaat, yang mengutamakan prinsip wetmatigheid. Konsep rechtstaat memberikan ciri-ciri ${ }^{1}$ :

${ }^{1}$ Mahmud MD. Konsepsi dan Implementasi Negara Hukum Kita, dalam Orasi Ilmiah Siding Terbuka STIH IBLAM, Pasca Sarjana Magister Ilmu Hukum Thn 2003.

Perlindungan Indikasi Geografis Berdasarkan Peraturan Pemerintah ...| Nurohma 111 
1. Adanya perlindungan terhadap Hak Asasi Manusia

2. Adanya pemisahan dan pembagian kekuasaan negara untuk menjamin perlindungan Hak asasi manusia

3. Pemerintah berdasarkan peraturan, dan

4. Adanya peradilan administrasi

Indonesia memiliki potensi sumber daya alam yang begitu banyak seperti; Kopi Kintamani, Kopi Arabika Toraya, Lada Bangka, Markisa Medan, Cengkeh dan Pala Ternate, Minyak Kayu Putih Ambon, Kayu Manis Bukit Tinggi, Tembakau Hitam Sumedang, Kopi Arabika Gayo,Susu Kuda Sumbawa, Cengkeh Minahasa dan masih banyak lagi produk-produk lokal lainnya yang dapat dikatagorikan sebagai potensi indikasi geografis, dikarena tempat asal barang yang disebutkan merupakan ciri ke-khas-an dari daerah yang bersangkutan, yang sudah pasti produk yang dihasilkan memiliki mutu, kualitas dan karakter tertentu, akan tetapi produk-produk sebagaimana disebut diatas belum diberi perlindungan atasnya karena masih merupakan permohonan yang didaftarkan.

Pada intinya konsep dasar indikasi geografis sangat sederhana, tetapi ketika dikaitkan dengan perlindungan hukum, maka masing-masing negara menjadi sangat kompleks perlindungannya karena implementasinya tergantung pada pendekatan dari masing-masing negara terhadap peraturan atau kebijakannya, terutama yang berkaitan dengan persaingan sebab kualitas suatu produk apabila telah diketahui mutu, ciri khas dan karakteristik produk tersebut.

Dengan era globalisasi dibidang perdagangan dunia sekarang ini, dituntut pemerintah Indonesia mengkaji ketentuan hukum yang telah ada untuk melindungi produk-produk masyarakat yang berindikasi geografis. Upaya ini harus dilakukan segera dengan mempertimbangkan adanya nama produk lokal Indonesia yang banyak diambil oleh pihak luar tanpa sepengetahuan masayarakat lokal yang kemudian dikembangkan menjadi miliknya sehingga memberi nilai ekonomi yang cukup besar bagi negaranya.

Fenomena ini seharusnya melekat langsung kepada produsen atau pemilik produk lokal yakni masyarakat itu sendiri melalui aparat pemerintah pusat maupun pemerintah daerah, seperti Dirjen Hak Kekayaan Intelektual Kementerian Hukum dan HAM RI, Dinas Peridustrian dan Perdagangan, Dinas Koperasi UMKM, Aparat Penegak Hukum diantaranya pihak Kepolisian khususnya bagian Reserse, Kejaksaan, Hakim pada PN untuk dapat melindungi produk lokal yang berkatagori indikasi geografis, tapi ironisnya aparat pemerintah telah mengetahui perlindungan produk-produk lokal berdasarkan sosialisasi yang dilakukan, namun sisi lain masyarakat sendiri malah hampir dikatakan belum mengetahui tentang indikasi geografis dan perlindungannya.

Sebagai contoh beberapa waktu yang lalu kasus "Kopi Toraja" dari Indonesia yang terkenal telah didaftarkan di Jepang dan Amerika, yang tanpa sepengetahuan masyarakatnya sendiri kopi tersebut telah mempunyai reputasi sedemikian tinggi hingga dikenal luas baik didalam maupun di luar negeri, dan sejauh ini pula masyarakat Indonesia mengakui bahwa reputasi kopi toraja adalah sebagai bagian dari fenomena bisnis dan perdagangan suatu produk, dimana produk yang mempunyai reputasi Internasional akan diikuti oleh praktek peniruan, termasuk dalam bentuk dan cara penggunaan nama-nama produk yang sudah terkenal tersebut. Padahal Toraja sendiri adalah nama daerah di Sulawesi yang menunjuk indikasi geografis. Kopi Toraja yang sudah terkenal dan telah mempunyai reputasi, didaftarkan sebagai Merek dengan tiga sistim pendaftaran dengan menggunakan kata TORAJA dengan gambar rumah Torajanya

Berdasarkan penulisan diatas, maka yang menjadi rumusan masalah apakah Peraturan Pemerintah Nomor 51 Tahun 2017 tentang Indikasi Geografis dapat melindungi produkproduk masyarakat lokal

112 Nurohma| Perlindungan Indikasi Geografis Berdasarkan Peraturan Pemerintah ... 


\section{B. METODE PENELITIAN}

Jenis penelitian yang digunakan penulis adalah penelitian hukum normatif. Penelitian hukum normatif adalah penelitian hukum yang meletakkan hukum sebagai sebuah bangunan sistem normatif dengan menggunakan metode pendekatan: Pendekatan perUndang-Undangan (statute approach), Pendekatan konspetual (conceptual approach), dan Pendekatan kasus (case approach).

\section{PEMBAHASAN}

\section{Pengertian IG}

Bagi Indonesia ketentuan indikasi geografis masuk dalam ketentuan hukum merek, sekilas terlihat merek dapat melindungi indikasi geografis padahal sistem perlindungan merek berbeda dengan sistem perlindungan indikasi geografis, dimana merek dilindungi secara individual sedangkan indikasi geografis dilindungi secara komunal, kemudian sifat merek tidaklah menunjukan kualitas produk, indikasi geografis menunjukan kualitas, reputasi dan karakteristik termasuk georafis dimana produk tersebut berada di wilayah penghasilnya.

Dalam praktek memang dimungkinkan adanya pemakaian merek dan indikasi gografis secara berdampingan untuk produk yang sama. Kalau dilihat hukum merek.

Indikasi Geografis merupakan sub bagian dari undang-undang Nomor 15 Tahun 2001 tentang Merek pada pasal 56 merumuskan indikasi geografis dilindungi sebagai suatu tanda yang menunjukkan daerah asal suatu barang yang karena faktor lingkungan geografis, termasuk alam, faktor manusia, atau kombinasi kedua faktor tersebut.

Dalam penjelasan pasal tersebut diartikan sebagai berikut, Indikasi Geografis adalah suatu indikasi atau identitas dari suatu barang yang berasal dari suatu tempat, daerah atau wilayah tertentu yang menunjukkan adanya kualitas, reputasi dan karakteristik termasuk faktor alam dan faktor manusia yang dijadikan atribut dari barang tersebut.

Tanda yang digunakan sebagai indikasi geografis dapat berupa etiket atau label yang dilekatkan pada barang yang dihasilkan. Tanda tersebut dapat berupa nama tempat, daerah, atau wilayah, kata, gambar, huruf, atau kombinasi dari unsur-unsur tersebut. Pengertian nama tempat dapat berasal dari nama yang tertera dalam peta geografis atau nama yang karena pemakaian secara terus-menerus sehingga dikenal sebagai nama tempat asal barang yang bersangkutan. Perlindungan indikasi-geografis meliputi barang-barang yang dihasilkan oleh alam, barang hasil pertanian, hasil kerajinan tangan; atau hasil industri tertentu lainnya".

Untuk mempermudah kita akan indikasi geografis maka,beberapa ketentuan telah mengatur indikasi geografis terlebih dahulu seperti, ketentuan Convensi Paris, Madrid Agreement dan Lisbon Agremeent yang kemudian dipertegas lagi dalam ketentuan TRIPs Agreement.

Convensi Paris pada Pasal 1 (2) menyebutkan perlindungan tentang "Indication of Source" atau "Appelation of Origin" yang merupakan salah satu bagian dari obyek perlindungan konvensi yaitu :

"The Protection of Indrustrial Property has as its object patents, utility models, industrial design, trade marks, service marks, trade names, indication of source or appelation of origin, and the repression of unfair competition"

Madrid Agreement memberikan rumusan perlindungan yang lebih luas tentang Indikasi Geografis yang dirumuskan dalam Pasal 1 (1) sebagai berikut:

"All goods bearing a false or deceptive indication by which one of the countries to which this agreement applies or a place situated therein, is directly or indirectly indicated as being the country or place or origin shall be seized on importation into any of the said countries." 
Lisbon Agreement mengatur tentang Indikasi Geografis secara lebih luas lagi yang ruang lingkup pengaturannya mencakup sistem pendaftaran atas Indikasi Geografis. Dalam Agreement tersebut Indikasi Geografis dinyatakan sebagai Appelation of Origin yang secara definitif dirumuskan dalam Pasal 2 WIPO, sebagai berikut:

"The geographical name of a country, region, or locality, which serves to designate a product originating there in, the quality and charateristic of which are due exclusively or essentially to the geographical environment, including natural and human factors".

Dari uraian di atas dapat disimpulkan bahwa indikasi geografis adalah salah satu rezim Hak Kekayaan Intelektual dan merupakan indikasi yang dapat meningkatkan hubungan erat antar produk dengan tempat asalnya. Hubungan erat tesebut berasal dari pengaruh faktor alam yang mempengaruhi reputasi produk tersebut. Faktor alam ini dominan, tetapi sebagai satu hak yang berkaitan dengan intelektualitas tentulah memerlukan faktor intervensi manusia, dan intervensi ini bervariasi.

Seperti yang telah dikatakan diatas sistim perlindungan terhadap indikasi geografis yang diatur dalam Perjanjian TRIP's mewajibkan negara-negara anggota untuk menyusun peraturan tentang Indikasi Geografis dengan tujuan memberikan perlindungan hukum terhadap produkproduk lokal agar terhindar dari praktek dan tindakan persaingan curang.

Penggunaan indikasi geografis dalam perkembanganan di dunia internasional sekarang ini semakin meningkat apalagi negara-negara berkembang seperti di Cina, Vietnam, Thailand, Indonesia, Meksiko, Korea dan lain sebagainya, melihat indikasi geografisnya memiliki peran yang strategis dalam dunia ekonomi, antara lain sebagai :

1. Sarana pelindung baik bagi produsen maupun konsumen

2. Sebagai sarana pemasaran

3. Sebagai sarana pembangunan bagi daerah pedesaan, dan

4. Sebagai sarana pemerataan ekonomi. ${ }^{2}$

Membuat negara-negara tersebut untuk mengakseskan program-program yang bertujuan untuk melindungi produk-produk yang menjadi kekayaan negaranya.

TRIP's sendiri memberikan dua kewenangan kepada negara-negara anggotanya untuk mencegah pihak lain melanggar hak berdasarkan indikasi geografis, yakni :

1. Pengguna setiap cara penunjukan barang yang merujuk atau menjanjikan bahwa barang tersebut berasal dari daerah geografis, selain dari tempat asal yang sebenarnya sehingga menyesatkan publik mengenai asal geografis dari barang tersebut ;

2. Setiap penggunaan yang menunjukkan adanya perbuatan persaingan curang.

Melihat kondisi sekarang ini dengan adanya globalisasi dibidang perdagangan dunia maka dituntut untuk Pemerintah Indonesia mengkaji ketentuan hukum indikasi geografis secara tersendiri, sekalipun nampaknya merek dan indikasi geografis keduanya mempunyai fungsinya yang sama yakni, mempromosikan suatu produk, tetapi berbeda dalam pelaksanaannya, sehingga perlu dilakukan harmonisasi terhadap pengaturannya. Upaya ini harus dilakukan segera dengan mempertimbangkan adanya nama produk lokal Indonesia yang diambil oleh pihak luar tanpa sepengetahuan masayarakat lokal.

Ketentuan indikasi geografis sampai saat ini pada prakteknya belum berjalan secara optimal. Ketentuan indikasi geografis yang diberlakukan selama ini hanya berkisar pada sosialisasi baik itu ditingkat internasional yang dilakukan di Indonesia maupun di Indonesia sendiri yang dilakukan hanya sebatas pada aparat pemerintah terutama pada instansi-instansi terkait dalam

${ }^{2}$ Delphine Marie-Vivvien."Geographical Indication and International Legal Framework”. Dalam Liputsan Khusus, Media HKI. Vol.II/No.1/April 2004, hlm. 29

114 Nurohma | Perlindungan Indikasi Geografis Berdasarkan Peraturan Pemerintah ... 
bidang ini. Padahal fenomena ini seharusnya melekat langsung kepada produsen atau pemilik produk lokal yakni masyarakat itu sendiri.

Di sinilah terjadi ketidak seimbangan dalam penerapan memberlakukan perlindungan akan indikasi geografis, satu sisi aparat pemerintah seperti Dirjen HKI Kementerian Hukum dan HAM RI, Dinas Peridustrian dan Perdagangan, Dinas Koperasi UMKM, aparat penegak hukum diantaranya pihak Kepolisian khususnya bagian Reserse, Hakim pada PN telah mengetahui perlindungan akan indikasi geografis, tapi sisi lain masyarakat sendiri malah hampir dikatakan belum mengetahui tentang indikasi geografis dan perlindungannya.

\section{Produk Masyarakat Lokal yang berindikasi geografis}

Indonesia terletak diantara dua benua Asia dan Australia yang terdiri dari ribuan pulau, memiliki teritorial yang sangat luas, sehingga kondisi geografis dan sosial budaya antar kawasan sangat beragam. Data Survey menunjukkan, indonesia memiliki keanekaragaman hayati yang begitu besar baik didarat maupun dilaut, fakta itulah menjadikan Indonesia dikenal sebagai negara dengan mega sumber keanekaragaman hayati. Kondisi ini sudah barang tentu berdampak pada beragamnya produk yang dihasilkan antara kawasan.

"Produk Masyarakat lokal mengacu pada produk-produk yang berada di wilayah Indonesia seperti, Lada Lampung,Tembakau Deli, Coklat Bone, Pala Ternate, Beras Cianjur, Kayu Manis Bukit Tinggi, Salak Pondoh, Markisa Medan, Markisa Makassar, Kayu Putih Ambon, Cengkeh Ternate, Mangga Indramayu, Kopi Toraja, Ukiran Kayu Asmat, Kopi Kintamani, Beras Cianjur". ${ }^{3}$ dan masih banyak lagi produk-produk kedaerahan yang yang berindikasi geografis seperti kerajinan tangan seperti gerabah dan hasil industri lainnya.

Indonesia memiliki beragam produk pertanian, baik segar maupun olahan. Hampir tiap daerah di Indonesia memiliki produk unggulan yang menjadi ciri khas daerah tersebut. Produk unggulan tersebut berpotensi diajukan sebagai produk indikasi geografis guna mendapatkan perlindungan dari upaya pemalsuan yang dapat mengurangi/ merusak reputasinya.

Patut diketahui juga bahwa banyaknya jumlah produk yang didaftarkan tapi juga untuk mengindikasikan paling tidak dua hal, (1) adanya permintaan terhadap produk-produk indikasi geografis; dan (2) tingginya minat produsen untuk melindungi produk-produknya dari kemungkinan upaya penyalahgunaan/ pemalsuan. Selain itu, keberadaan undang-undang dan peraturan pemerintah yang mengatur indikasi geografis juga harus menguatkan. Catatan juga walaupun telah ada indikasi permintaan terhadap produk indikasi geografis, riset pasar dan kebijakan publik, baik yang berskala lokal maupun nasional tetap diperlukan untuk memperoleh informasi permintaan pasar yang lebih akurat. Disisi lain, keberagaman latar belakang sosial budaya masyarakat di Indonesia memerlukan kajian riset berskala lokal yang ketika dikumpulkan kedalam suatu basis data nasional dapat memberikan informasi pasar berskala nasional yang kemudian kebijakan indikasi geografis berdampak pada perbaikan kesejahteraan petani/ produsen produk berindikasi geografis

\section{Gambaran ketentuan IG}

Perlindungan IG pertama kali diatur dalam UU Nomor 14 Tahun 1997 tentang Merek setelah Indonesia meratifikasi ketentuan WTO-TRIP's yang kemudian ditetapkan dalam UU Nomor 7 Tahun 1994 tentang Pengesahan Persetujuan Pembentukan Organisasi Perdagangn Dunia (WTO), yang kemudian diatur kembali dalam UU Nomor 15 Tahun 2001 tentang Merek, dan IG diatur dalam pasal 56 sampai pasal 58. Dalam undang-undang tersebut pengaturan

\footnotetext{
${ }^{3}$ Abdul Bari Azed, Kepentingan Negara Berkembang atas Indikasi Geografis, Sumberdaya Genetik dan Pengetahuan Tradisional, Lembaga Pengkajian Hukum Universitas Indonesia Kerjasama dengan Ditjen HKI, Perpustakaan Nasional RI. hlm.9-10.
} 
mengenai perlindungan indikasi geografis mengikuti standar yang ditetapkan dalam TRIP's Agreement.

Indikasi geografis yang sudah terdaftar menghasilkan hak atas indikasi geografis. Pasal 1 angka 7 UUMIG menyatakan hak atas indikasi geografis adalah hak eksklusif yang diberikan oleh negara kepada pemegang hak indikasi geografis yang terdaftar, selama reputasi, kualitas, dan karakteristik yang menjadi dasar diberikannya pelindungan atas indikasi geografis tersebut masih ada. Hak atas indikasi geografis tersebut memiliki arti strategis secara hukum dan secara ekonomi kepada pemiliknya dalam memanfaatkan produk indikasi geografis. Hal ini merupakan keunggulan kompetitif yang dapat meningkatkan daya saing produk indikasi geografis yang bersangkutan. Apalagi berdasarkan Pasal 61 ayat (1) UUMIG, indikasi geografis dilindungi selama terjaganya reputasi, kualitas, dan karakteristik yang menjadi dasar diberikannya pelindungan indikasi geografis pada suatu barang. Artinya mendapat perlindungan hukum selama-lamanya sepanjang memenuhi dapat menjaga reputasi, kualitas, dan karakteristik dari indikasi geografis tersebut.

Di era persaingan global ini, hak atas indikasi geografis sangat penting karena pemegangnya terlindungi dari pelanggaran sebagaimana tercantum pada Pasal 66 UUMIG, yaitu:

a. pemakaian indikasi geografis, baik secara langsung maupun tidak langsung atas barang dan/ atau produk yang tidak memenuhi dokumen deskripsi indikasi geografis;

b. pemakaian suatu tanda indikasi geografis, baik secara langsung maupun tidak langsung atas barang dan/atau produk yang dilindungi atau tidak dilindungi dengan maksud untuk:

1. menunjukkan bahwa barang dan/atau produk tersebut sebanding kualitasnya dengan barang dan/atau produk yang dilindungi oleh indikasi geografis;

2. mendapatkan keuntungan dari pemakaian tersebut; atau

3. mendapatkan keuntungan atas reputasi indikasi geografis.

c. pemakaian indikasi geografis yang dapat menyesatkan masyarakat sehubungan dengan asalusul geografis barang itu;

d. pemakaian indikasi geografis oleh bukan pemakai indikasi geografis terdaftar;

e. peniruan atau penyalahgunaan yang dapat menyesatkan sehubungan dengan asal tempat barang dan/atau produk atau kualitas barang dan/atau produk yang terdapat pada:

1. pembungkus atau kemasan;

2. keterangan dalam iklan;

3. keterangan dalam dokumen mengenai barang dan/atau produk tersebut; atau

4. informasi yang dapat menyesatkan mengenai asal-usulnya dalam suatu kemasan.

f. tindakan lainnya yang dapat menyesatkan masyarakat luas mengenai kebenaran asal barang dan/atau produk tersebut.

Pelanggaran terhadap hak atas indikasi geografis tersebut dapat diselesaikan secara perdata dan pidana. Secara perdata pihak yang merasa telah dirugikan dapat mengajukan gugatan ganti rugi kepada pihak yang melakukan pelanggaran. Gugatan ganti rugi dapat diselesaikan di luar pengadilan (negosiasi, mediasi, arbitrase), dan di pengadilan melalui Pengadilan Niaga.

Selanjutnya perlindungan secara Pidana atas Indikasi Geografis Katakan apabila pihak yang merasa telah dirugikan dapat melaporkan pihak pelanggar ke Kepolisian Republik Indonesia setempat sesuai dengan ketentuan Pasal 101 UUMIG yang menyatakan:

(1) setiap orang yang dengan tanpa hak menggunakan tanda yang mempunyai persamaan pada keseluruhan dengan indikasi geografis milik pihak lain untuk barang dan/atau produk yang sama atau sejenis dengan barang dan/atau produk yang terdaftar, dipidana dengan pidana penjara paling lama 4 (empat) tahun dan/atau denda paling banyak Rp.2.000.000.000,00 (dua miliar rupiah).

116 Nurohma | Perlindungan Indikasi Geografis Berdasarkan Peraturan Pemerintah ... 
(2) Setiap orang yang dengan tanpa hak menggunakan tanda yang mempunyai persamaan pada pokoknya dengan indikasi geografis milik pihak lain untuk barang dan/atau produk yang sama atau sejenis dengan barang dan/atau produk yang terdaftar, dipidana dengan pidana penjara paling lama 4 (empat) tahun dan/atau denda paling banyak Rp.2.000.000.000,00 (dua miliar rupiah).

Dengan berlakunya UU Nomor 20 Tahun 2016 tentang Merek dan Indikasi Geografis yang menggantikan UU Nomor 15 tahun 2000 maka Perlindungan atas Indikasi Geografis pada pasal 53 menjadi :

1. IG dilindungi setelah IG didaftarkan oleh Menteri

2. Untuk memperoleh perlindungan sebagaimana dimaksud ayat (1), permohonan IG harus mengajukan permohonan kepada Menteri

3. Permohonan sebagaimana pada ayat (2) merupakan :

a. lembaga yang mewakili masyarakat dikawasan geografis tertantu yang mengusahakan suatu barang dan/atau produk berupa :

1. Sumber Daya Alam;

2. Barang Kerajinan Tangan; atau

3. Hasil Industri

b. Pemerintah Daerah Provinsi atau Kabupaten/Kota

Pada pasal 54 dikatakan :

1. Permohonan yang diajukan oleh pemohonyang bertempt tinggal atau yang berkedudukan tetap di luar wilayah Negara Kesatuan republic Indonesia wajib dilakukan melalui kuasanya di Indonesia

2. Permohonan sebagaiman dimaksud pada ayat (1) hanya dapat didaftarkan apabila indikasi geografis tersebut telah memperoleh pengakuan dari pemerintah negaranya dan/atau terdaftar sesuai dengan ketentuan yang berlaku dinegara asalnya

Pada pasal 55 dikatakan juga :

1. IG dapat pula didaftarkan berdasarkan perjanjian internasional

2. Ketentuan lebih lanjut mengenai pendaftaran Ig dari luar negeri sebagaimana dimaksud dalam pasal 54 diatur dengan peraturan Menteri.

Selanjutnya pada Peraturan Pemerintah No. 51 Tahun 2007 tentang indikasi geografis mengatur ruang lingkupnya meliputi :

a. Ketentuan umum

Ketentuan umum berisikan definisi IG sebagaimana yang definisi terdapat pada pasal 1 point (1) dan lingkup IG terdapat pada pasal 2, kemudian pengaturan mengenai persyaratan terdapat pada ayat (5 dan 6) sebagai suatu dokumen yang memuat informasi tentang kualitas dan karakteristik yang khas dari barang yang dapat digunakan untuk membedakan barang yang satu dengan yang lain yang memiliki katagori yang sama. Selanjutnya pada pasal 6 ayat (3) mengatur tentang buku persyaratan yang mengatur nama barang, dan lingkungan dimana barang itu berada serta tanda yang ditempatkan pada produk untuk melindungi indikasi geografis yang sudah didaftarkan dalam daftar umum IG di Ditjen KI, sehingga IG tersebut tidak dapat berubah menjadi milik umum (bersifat generik).

Selain tanda yang memiliki ciri khas tersendirijuga menentukan batas-batas yang meliputi iklim atau kondisi geografis daerah tertentu, atau teritorial suatu daerah atau kondisi alam yang berbeda satu dengan yang lain dimana produk yang dihasilkan memang benar-benar ada, tumbuh dan berkembang pada daerah tertentu tersebut.

b. Indikasi geografis yang tidak terdaftar.

Pada pasal 3 pengaturan indikasi geografis, mengatur tentang indikasi geografisyang tidak dapat didaftarkan, yakni : bertentangan dengan peraturan perundang-undangan, moralitas 
agama, kesusilaan danketetiban umum, menyesatkan atau memperdaya masyarakat mengenai ciri, sifat, kualitas, asal sumber, proses pembuatan perlatan barang, dan/atau kegunaannya.

c. Jangka waktu perlindungan

Berdasarkan pasal 4 indikasi geografis mendapat perlindungan selama karakteristik khas dan kualitas yang menjadi dasar bagi diberikannya perlindugan atas indikasi geografis tersebut masih ada.

d. Tata cara pendaftaran

Secara konseptual, subtansi hukum menunjukan pada aturan atau ketentuan dalam peraturan perundangan yang ada. ${ }^{4}$ Oleh karenanya Ketentuan IG yang ada dalam UU Merek menjadi fokus kajian dan apa yang disebut Yehezkel Dror ${ }^{5}$ sebagai hukum subtantif (subtantive law), pembahasan tentang IG perlu dikaitkan dengan peraturan perundangundangan lainnya, baik dalam kaitan vertikal maupun horisontal. Secara vertikal IG dalam ketentuan merek merupakan penjabaran dari UUD 945 pada pasal 5 ayat (1) pasal 20 dan pasal 33. Berdasarkan subtansi IG melekat hak ekonomi dan hak moral, hak ekonomi adalah hak untuk mendapat manfaat atas hasil yang didapat dari produk-produk lokalnya sedangkan dan hak moral adalah hak yang melekat pada masyarakat yang memproduksi produk-produk lokal. Ketentuan IG harus mampu menonjolkan nilai-nilai keberadaan manusia Indonesia untuk melindungi produk-produk lokalnya, dan diharapkan perlindungannya menjadi efektif bagi semua produk lokal yang berada di Indonesia sehingga pihak luar tidak melakukan pengambilan produk-produk lokal untuk kepentinganya dan mencari keuntungan. Untuk itu dengan melakukan perlindungan atas produk-produk lokal, maka IG dapat mendorong penanaman modal asing untuk melakukan kerjasama dalam memanfaatkan produk-produk lokal.

\section{Upaya Perlindungan atas IG}

Sistem undang-undang Kekayaan Intelektual Modern yang berkembang pesat secara globalisasi dan seragam telah mempermudah dan mempertinggi proses eksplotasi ekonomi dan erosi kebudayaan masyarakat asli, hal ini karena peraturan perundang-undanga KI didasarkan pada konsep "kepemilikan" kekayaan atau property, dimana penduduk asli merupakan sesuatu yang asing dan tidak menguntungkan, yang tujuannya untuk mengakui hak-hak perorangan atas benda yang berharga, sedangkan ada juga pandangan penduduk asli lebih memprioritaskan pada kepentingan-kepentingan komunitas secara keseluruhan atas kebudayaan dan produkproduk lokal yang bersifat kolektif.Selain itu juga, faktor budaya berpengaruh pada pandangan masyarakat menyangkut nilai ekonomi. Masyarakat sebagai pemilik produk-produk didaerah sama sekali tidak memeperhitungkan keuntungan nilai ekonomi dan tidak memiliki keinginan untuk melindungi produk-produk mereka sebagai aset dari pengambilan pihak asing.

Keanekaragaman hayati Indonesia yang mempunyai nilai ekonomis yang sangat tinggi perlu membentuk perlindungan atasnya, baik itu yang ada hubungannya dengan pertanian, kerajinan tangan, perindustrian lainnya, pengetahuan tradisional, kebudayaan yang juga didasarkan dalam sistim Hak Kekayaan Intelektual.

Pemerintah Indonesia sudah sepantasnya melindungi apa yang menjadi hak-hak masyarakat atas sumber daya alam dan hayati, sekalipun disatu sisi masyarakat sendiri belum menyadari bahwa arti kemanfaatan dan nilai ekonomi yang didapat dari sumber daya alam dan hayatitersebut memberikan kesejahteraan bagi masyarakat setempat dan memberikan keberhasilan pada sektor perindustrian dan perdagangan.

${ }^{4}$ Lawrence M Friedman, The Legal Sistem ...Op Cit...hlm. 17

${ }^{5}$ Yehezkel Dror,Ventures and Policy Scince Conceptsand Application, New York, Elsevier, 1981. hlm. 170.

118 Nurohma | Perlindungan Indikasi Geografis Berdasarkan Peraturan Pemerintah ... 
Indikasi geogrfis merupakan salah satu tanda dari produk yang dihasilkan yang dikarenakan faktor alam ataupun faktor geografis, pengaturan perlindungan akan diberikan kepada lembaga, produsen atau perusahaan yang mendaftarkannya atas nama masyarakat lokal.

Ketentuan Pasal 53 ayat (3) dan (2) Undang-undang No. 20 Tahun 2017 adalah sebagai landasan untuk menata perlindungan Indikasi Geografis atas produk-produk masyarakat lokal sesuai dengan tujuan yang dikehendaki oleh instrumen kebijakan yang mempunyai arti penting dalam kehidupan sosial masyarakat lokal

Pada tingkat filosifis, perlindungan atas IG merupakan cerminan cita hukum Pancasila, khususnya keadilan sosial bagi seluruh rakyat, yakni mengutamakan adanya perlakuan yang adil atas pemberlakuan produk-produk lokal, dalam artian masyarakat sebagai yang empunya produk lokal diberikan kesempatan dalam mengelola produk lokalnya sehingga tidak dikelola secara individi atau oleh pihak luar begitu saja dan merugikan masyarakat lokal.

Secara horisontal ketentuan IG dalam UU Merek ini memiliki kesinambungan dengan UU Nomor 5 tahun 1999 tentang Larangan Praktek Monopoli dan Persaingan Usaha Tidak Sehat. Ketentuan IG lebih ditekankan pada perlindungan pada suatu tanda yang menunjukkan suatu daerah atau barang yang dipengaruhi oleh faktor alam dan manusia dan produk barang yang dihasilkan tersebut mempunyai ciri dan kualitas tertentu. Selama ini perlindungan terhadap tanda yang diberikan atas suatu produk yang dihasilkan berdasarkan IG tidak pernah dilakukan sebagaimana tertera pada ketentuan umum, tanda yang diberikan tersebut hanya lebih banyak diberlakukan pada merek sehingga merek dikatakan monopoli atas IG, yang selanjuntnya apabila dikaitkan dengan pasal 1 UU Larangan Monopoli dan Persaingan Usaha Tidak sehat menitik beratkan pada persaingan tidak sehat adalah persaingan antara pelaku usaha dalam melakukan kegiatan produksi dan atau pemasaran barang dan jasa dilakukan dengan tidak jujur atau melawan hukum atau menghambat persaingan usaha.

Hal lain yang timbul dari pada pemakaian suatu tanda IG pada merek adalah bahwa negara luar telah lebih dulu mendaftarkan produk-produk lokal yang dikelola didalam negeri dengan merek yang diinginkan mereka sehingga perberlakuan pendaftaran yang akan dilakukan oleh kelompok masyarakat atas IG tidak dapat dilakukan karena telah didaftarkan lebih dulu dengan merek yang kemudian apabila berkaitan dengan penyalagunaan yang dilakukan pihak luar atas pengambilan produk-produk lokal dari masyarakat lokal, ketentuan dalam KUP Perdata yang terkait dengan IG pada pasal 1365 menyatakan bahwa:

"tiap perbuatan yang melanggar hukum dan membawa kerugian kepada orang lain, mewajibkan orang yang menimbulkan kerugian itu karena kesalahannya untuk menggantikan kerugian itu”.

Ketentuan diatas merupakan suatu ketentuan untuk melindungi konsumen dari penyalagunaan pemakaian hak secara monopoli terutama pada pemakaian nama produk lokal yang dikatagorikan dalam IG.

Pada dasarnya, sistem perlindungan atas IG mempergunakan sistem fir st to file yang diartikan hak IG diberikan pada pendaftar pertama. Dengan demikian siapa yang mendaftarkan lebih duluan maka ia yang berhak atas hak tersebut.

Secara lebih mendasar ketentuan IG memiliki konsepsi dan tujuan yang cukup baik, namun secara faktual berdasarkan temuan emperis ditemukan sejumlah persoalan yang bersifat sosio-yuridis menyangkut subtansi dari ketentuan tersebut baik itu berkaitan langsung dengan UU maupun Peraturan pemerintah, halmana apabila dikaitkan dengan pendaftaran untuk melindungi produk lokal maka persoalan yuridis akan muncul.

Secara katagorial yang perlu di bahas disini adalah soal tujuan dan kepentingan yang diindungi. Masalah tujuan dan kepentingan yang dilindungi merupakan bagian yang secara umum perlu mendapat perhatian, tujuan pertama adalah iklim untuk melakukan pendaftaran 
agar pihak lain tidak memanfaatkan produk-produk masyarakat lokal yang berpotensi IG begitu saja yang kemudian melakukan pendaftaran atasnya. Ketentuan ini diharapkan agar pihak luar tidak menganggu produk hasil kita sehingga terjalin hubungan dengan baik.

Secara emperik juga tawaran ini tidak sesuai dengan kenyataan yang sesungguhnya, bahwa pihak luar malah yang melakukan pemanfaatan atas produk-produk masyarakat lokal bahkan melakukan pendaftaran. Pengalaman yang terjadi pada kasus kopi Toraja yang didaftarkan dengan merek oleh phak luar, yang kemudian kasus ini tidak dapat diselesaikan dengan jalur hukum, sebab sikap sosial yang terlalu berperspektif budaya, tujuan kedua adalah ketentuan tersebut dimaksud untuk melindungi hak eksklusif atas pemakaian IG.

Masyarakat lokal sebagai pemilik produk-produk lokal haruslah dapat melindungi produk lokalnya dengan melakukan pendaftaran sebab dengan begitu maka hak eksklusif telah melekat pada masyarakat sehingga orang lain yang ingin memanfaatkan produk-produk tersebut harus mendapat ijin untuk meggunakannya sebab pada kenyataannya terjadi pemakaian atas IG untuk produk-produk lokal merupakan monopoli perorangan yang merugikan masyarakat lokal, tujuan ketiga adalah melalui ketentuan IG dapat menciptakan rasa aman dan kepastian hukum atas pemakaian produk-produk lokal dan masyarakat dipicu agar dapat mencari pasar untuk pendistribusian produk-produk lokal yang ada, sehingga dapat dirasakan manfaatnya untuk kesejahteraan masyarakat lokal. Tujuan ketiga ini untuk menghindari pihak ketiga dalam melakukan pendistribusian yang dilakukan tanpa sepengetahuan masyarakat lokal karena mereka telah melakukan pengambilan produk-produk masyarakat lokal untuk dimanfaatkan demi kepentingan mereka.

Dari data lapangan terlihat bahwa pembuatUU initidak didahului dengan studiyang mendalam apalagi berkaitan dengan situasi yang dihadapi masyarakat lokal untuk melindungi produkproduknya. UU ini dibuat atas dasar masuk dan ikut serta Indonesia dalam penandatanganan TRIP's Agreement yang mau tidak mau secepat mungkin dilakukan pembuatan UU ini yang tanpa mempertimbangkan.

Sejak UU Nomor 15 tahun 2001 tentang Merek diberlakukan implementasi perlindungan IG belum dilakukan oleh pihak pemerintah, akibatnya ketentuan IG sangat sulit untuk berfungsi didalam masyarakat.

Menurut Sakki Septiano ${ }^{6}$ pemerintah harus membuat UU tersendiri tentang IG supaya jelas dalam peruntukannya karena IG sangat berbeda dengan Merek yang kemudian bukan saja pada subtansi perlindungannya tetapi pada stuktur yakni organisasi pelaksananya sebab sekalipun telah ada Peraturan Pemerintah yang mengaturnya, organisasi yang berada didalamnya masih tetap pada sistem merek.

Pada ketentuan pasal 53 ayat (3) UU Nomor 20 tahun 2017 tentang Merek dan IG merupakan sarana perlindungan hukum bagi IG yang mengandung 2 (dua) bentuk perlindungan stelsel yakni :

1. Stelsel Deklaratif adalah pemakaian pertama itulah yang berhak atas Merek, artinya sistem ini mempunyai karakter formal yang sangat efisien dari segi waktu, biaya, dan prosedur yang tidak rumit sesuai dengan karakter masyarakat traditional lokal yang tidak terbiasa dengan hal tulis menulis dan biasanya kepemilikannya adalah secara bersama-sama tidak seperti rezim HKI pada umumnya.

2. Stelsel Konstitutif (atributif) adalah yang mendaftar pertamalah yang berhak atas merek dan secara eksklusif dapat memakai merek tersebut sehingga hak eksklusif suatu merek diberikan karena adanya pendaftaran dengan dikeluarkannya sertifikat terdaftar. Patut dicatat sistem ini memang membutuhkan waktu yang cukup lama tetapi dengan adanya alat bukti tertulis

${ }^{6}$ Hasil wawncara dengan Saki Septioano salah satu Kasubbid Perlindungan IG pada Dirjen HKI Kementerian Hukum dan HAM RI pada bulan Pebruaru 2010. 
yaitu sertifikat dapat memberikan jaminan kepastian hukum bagi pemegang hak IG secara sah.

Dengan melihat pada 2 (dua) sistem yang ada maka implementasi atas IG masih pada tataran harapan dan kenyataan, karena belum berfungsi sebagaimana mestinya dalam memberikan kepastian hukum dan perlindungan kepada masyarakat sebagai pemegang hak.

Kepastian hukum adalah salah satu dari tujuan hukum, sebagaimana yang dikatakan Aristoteles ${ }^{7}$ bahwa memberikan kepada setiap orang apa yang berhak ia terima. Yang kemudian oleh Jeremi Bentham mengatakan tujuan hukum menjamin adanya kebahagiaan sebanyakbanyaknya, ${ }^{8}$ sementara Van Kant mengatakan pula tujuan hukum adalah untuk menjaga kepentingan tiap-tiap manusia supaya kepentingan itu tidak dapat diganggu. ${ }^{9}$

Tujuan hukum sebagaimana dikatakan adalah memberikan suatu kepastian hukum, kemanfaatan dan keadilan. Apalagi hukum sebagai alat instrumen rekayasa sosial (law as a tool as social engineering), yang sekarang ini lebih banyak didengungkan artinya segala sesuatu harus didasarkan dan diarahkan oleh aturan hukum, apalagi Indonesia seba30gai negara yang menganut supremasi hukum.

Berfungsinya hukum dalam masyarakat adalah merupakan suatu sarana pengendalian sosial dimana dikatakan bahwa fungsi hukum yang sangat esensial adalah fungsi untuk menjamin stabilitas dan kepastian sebagai tujuan utama hukum.

Berlakunya fungsi hukum didalam masyarakat, untuk memenuhinya kebutuhan masyarakat akan kehadiran akan fungsi hukum tersebut, maka Hoebel ${ }^{10}$ merumuskan fungsi hukum menjadi empat (1) untuk menjelaskan hubungan di antara anggata masyarakat, menjelaskan aktfitas yang boleh dan dilarang oleh hukum, (2) untuk mengukur alokasi kekuasaan dan penentu siapa yang boleh memaksa secara fisik yang diakui oleh masyarakat, termasuk pemilihan bentuk-bentuk sanksi fisik yang paling efektif untuk mencapai tujuan sosial, (3) sebagai sarana penyelesaian kasus-kasus sengketa yang timbul, (4) sebagai penjelas hubungan individu dan kelompok.

Fungsi hukum sebagaimana yang disebutkan Hoebel sebagi sarana sosial kontrol yakni mempertahankan pola-pola hubungan sosial dan norma-norma yang ada. Selanjutnya Muchtar Kusumaatmadja ${ }^{11}$ katakan fungsi hukum sebagai sarana perubahan yaitu (1) pemerintah menginginkan dan bahkan mutlak memerlukan keteraturan dan ketertiban dalam usaha pembangunan, (2) hukum sebagai kaedah atau peraturan hukum bisa berfungsi sebagai alat atau sarana penyelarasan kegiatan warga masyarakat kearah yang dikehendaki oleh pembangunan atau perubahan. Menurut Friedman ${ }^{12}$ fungsi hukum dalam masyarakat meliputi (1) pengendalian sosial (social control), (2) penyelesaian sengketa (dispute settelement), (3) rekayasa sosial (social engineering).

Untuk mengukur ketentuan hukum agar benar-benar berjalan sesuai fungsinya maka kesadaran hukum dan ketaatan hukum perlu di pahami oleh masyarakat karena berkaitan dengan efektifitasnya hukum yang berlaku dalam masyarakat.

Kesadaran hukum bukanlah suatu hal yang statis, melainkan berkembang sesuai dengan perkembangan. Oleh karenanya para pembentuk hukum harus tanggap terhadap perkembangan kesadaran hukum masyarakat, sehingga terciptanya berbagai produk hukum yang sesuai dengan kesadaran hukum dan bagi masyarakat Indonesia menjadi taat dalam melksanakan UU tersebut. Yang kemudian fungsi hukum digunakan sebagai saran perubahan masyarakat

${ }^{7}$ E Utrecht, Pengantar Dalam Hukum Indonesia, Djakarta. Balai Buku “Ichtisar”, Cetakan ke-empat, hlm. 20.

${ }^{8} \mathrm{Ibid}, \mathrm{hlm} .20$.

${ }^{9}$ Ibid., hlm. 21.

${ }^{10}$ Hoebel.(1968). The Law of Primitive Man. New York Atheneum, hlm. 275

${ }^{11}$ Muchtar Kusumaatmadja.(1976). Hukum, Masyarakat dan Pembinaan Hukum Nasional. Jakarta: Bina Cipta, hlm. 13

${ }^{12}$ L Friedman.(1977). The Legal System: A Social Science Perspective. New York: Russel Sage Foundation, hlm. 11. 
yang diartikan hukum menciptakan pola-pola baru yang mampu mendukung terciptanya pembangunan diberbagai sector.

Selain berfungsi sebagai mekanisme pengendalian sosial (social control), hukum juga berfungsi sebagai sarana perubahan masyarakat (law as a tool of social engineering). Apabila dihubungkan dengan PP Nomor 51 tahun 2007 tentang IG maka PP merupakan peraturan yang diatur untuk melengkapi UU yang telah ada namun sampai sekarangpun PP ini belum dapat berjalan optimal.

Kemudian permasalahan dalam konteks peraturan pemerintah Nomor 51 tahun 2007 pada pasal 6 ayat (3) dan (4) yang melekat pada persoalan tatacara atau persayaratan pendaftarannya.

Pada kenyataannya dalam UU Merek dan IG memang telah mengatur perlindungan atas produk-produk lokal, namun tidak mengatur tata cara persyaratan maupun mekanisme pendaftarannya sebagaimana UU Merek mengatur tata cara persyaratannya, tata cara dan mekanisme sedangkan IG diatur dalam Peraturan Pemerintah.

Bagi masyarakat lokal bila berlakunya suatu aturan apabila tanpa campur tangan pemerintah untuk melakukan pemahaman bagi mereka maka mereka tidak akan mengenal aturan tersebut.

Sejak UU Merek Nomor 14 tahun 1997 pada pasal 79 a s/d d mengatur ketentuan Merek yang kemudian dirubah dan diganti dengan UU Nomor 15 Tahun 2001 tentang Merek mengatur ketentuan IG pada pasal 56 s/d 58 serta pasal 53 s/d 55 UU Nomor 20 Tahun 2017 tentang Merek dan IG tidak memuat sistem pendaftaran IG sehingga perlindungan atas produk-produk lokal pada saat itu belumlah dapat didaftarkan, dan pada saat itu pula UU Merek lebih dominan sehingga para pengusaha yang memproduksi produk-produk lokal mendaftarkannya dengan Merek.

Apabila ditelusuri lebih jauh mengapa masyarakat belum melakukan pendaftaran atas produk-produk lokal hal ini karena : 1) masyarakat belum mengetahui akan ketentuan IG yang melekat pada UU Merek sebab selama ini merek yang lebih dominan; 2) masyarakat beranggap produk-produk lokal hanya dapat dipergunakan sekali pemakaian artinya produkproduk tersebut tidak perlu didaftarkan apabila terjadi penjualan maka dianggap selesai ; 3) masyarakat khususnya pelaku usaha lebih senang mendaftarkan produk-produk lokal yang dikelola dengan sistem merek, karena banyak memberikan manfaat dan dapat mencapai keuntungan.

O'Conner mengatakan syarat-syarat untuk didaftarkan sebagai indikasi geografis adalah sebagai berikut; (O’Connor, 2004;360) $)^{13}$

a. Merupakan barang;

b. Adanya faktor lingkungan geografis, termasuk faktor alam, faktor manusia, atau kombinasi keduanya dari suatu barang;

c. Memiliki ciri dan kualitas tertentu atau lebih tepatnya memiliki reputasi, yang telah dikenal tidak hanya dalam negeri saja melainkan sampai keluar negeri.

Beberapa contoh tanda yang dapat dikatakan sudah cukup terkenal yang menyangkut nama geografis dan telah mendapat perlindungan hukum dari negara pemiliknya berdasarkan pada pendaftaran adalah Champagne, Cognac, Havana dan Tequila. Nama-nama produk tersebut menunjukkan asal tempat, negara atau wilayah dimana produk tersebut dihasilkan. Dengan kata lain, ketika seseorang menyebut nama suatu produk dengan nama geografis maka orang akan mengaitkan produk tersebut dengan tempat asal dari produk yang bersangkutan. Karena kekhasan suatu produk seringkali juga menunjuk pada kualitas dan karakteristik, maka indikasi geografis dapat berfungsi sebagai identitas reputasi dari produk asli yang berasal dari 360.

${ }^{13} \mathrm{O}^{\prime}$ Conner.(2004). Sue Generis Protection of Geographical Indication, Darake Jurnal of Agricultural Law, Fall, . hlm. 
daerah atau wilayah tertentu. Karenanya, tanda tersebut dapat pula dikatakan mempunyai nilai kemanfaatan dan nilai ekonomi. Dengan demikian, penekanan konsep perindungan atas indikasi geografis ada pada ciri khas, kualitas, reputasi dan karakteristik yang melekat dengan lingkungan geografis.

Melihat dari keberadaan, indikasi geografis bagi Indonesia sendiri memiliki signifikan yang cukup tinggi, dikarenakan beberapa sebab ${ }^{14}$ :

1. Sebagai penandatangan perjanjian TRIP"s, adanya sistem perlindungan indikasi geografis yang implementatif ditingkat nasional dan akan meningkatkan integritas Indonesia dimata dunia internasional ;

2. Adanya keuntungan dari negara pemula untuk memilih sistem indikasi geografis yang cocok dengankepentingannasionaldalammasatransisiini.Karenasisitemimplementasiperlindungan indikasi geografis yang sekarang berlaku secara internasional masih amat beragam dan belum disepakatibersama, Indonesiadapatmempergunakankedaulatannyauntukmembangunsistem sendiri yang paling cocok bagi kepentingan nasional, sesuai dengan nilai-nilai masyarakat sendiri, sambil berpijak pada prinsip-prinsip dasar perjanjian TRIP"s

3. Karakteristik kepemilikan indikasi geografis yang kolektif atau komunalistik sejalan dengan nilai-nilai ketimuran dan keindonesiaan yang lebih menghargai kepemilikan bersama daripada kepemilikan pribadi ;

4. Keharusanadanyakaitanatauhubunganyangerat(stronglink)antaranamaatauindikasiproduk dengan kondisi geografis asal produk dalam rezim indikasi geografis tampak sejalan dengan sifat-sifat hukum masyarakat adat yang selalu menjunjung kebergantungan dan kelekatan eksistensinya dengan tanah asal. Potensi Indikasi geografis ini dapat dikembangkan untuk melindungi produk-produk masyarakat adat dan komunitas lokal yang umumnya memang dinamai bukan dengan nama individu, tetapi nama tempat asal suatu produk yang akan dilindungi dengan indikasi geografis ;

5. Jangka waktu perlindungan indikasi geografis yang terus menerus membuatnya berpotensi untuk melindungi keberlangsungan aset bangsa aset historis suatu komunitas lakal agar tetap tinggal dan bermanfaat bagi bangsa ataukelompok masyarakat pengembangnya sendiri ;

6. Dinegara maju sekalipun, misalnya Prancis, indikasi geografis merupakan salah satu rezim HKIyang telah terbuktimeningkatkanderajatekonomikomunitaslokalyangmiskin, terpencil, dan hanya memiliki satu sektor ekonomi andalan, untuk menjadi basis penguatan infrastruktur lokal yang independent. ${ }^{15}$

7. Dari unsur-unsur tersebut diatas, tampakjelas bahwa perlindungan terhadap indikasi geografis sangat penting untuk dikembangkan, di Indonesia, saat ini adalah saat yang paling tepat dimulainya untuk melindungi produk-produk lokal di Indonesia karena Indonsia telah ikut menandatangani perjanjian TRIP's tersebut.

Namun di satu sisi patut pula di sadari bahwa pada kenyataannya ironi bagi bangsa Indonesia tercatat sebagai negara yang banyak melakukan pelanggaran dibidang HKI yang merugikan negara luar yang mempunyai hak kekayaan intelektualnya, namun disisi lain Indonesia harus melindungi HKInya juga terutama produk-produk masyarakat lokal dari pihak luar.

Emawati Yunus, mengatakan ada beberapa manfaat dari pendaftaran atas indikasi geografis yaitu: ${ }^{16}$

1. Indikasi Geografis akan melindungi pengusaha dari persaingan yang tidak sehat;

2. Membantu mempromosikan produk-produk nasional ke pasar internasional;

\footnotetext{
${ }^{14}$ Miranda Risang Ayu, “ Perlindungan Hukum Indikasi Geografis: Suatu Tantangan Perlindungan Aset Bangsa Indonesia”. Media HKI. Vol.II/No.1/April 2004

${ }^{15}$ Denis Rochart.(2002). La Protection Internationale des Indications Geographiques, Paris: Presses Universitaires de France, hlm.359.

${ }^{16}$ Emawati Yunus, Suara Merdeka, 2000.
} 
3. Memberi reputasi iternasional;

4. Mendorong partisipasi masyarakat untuk memiliki produk bersama hasil kekayaan alam;

5. Memajukan industri pertanian rakyat;

6. Memberi nilai tambah bagi produk tersebut;

7. Bagi konsumen, itu menjadi jaminan kualitas barang;

8. Mendukung perkembangan dunia usaha yang kompetetif dan spesifik dipasar global, serta memberikanreputasiinternasionaldibidangeksportpadaprodukyangberkarakterdanmemiliki tradisi kebudayaan daerah

Masalah pendaftaran atas indikasi geografis untuk mendapat perlindungan didasarkan pada prosedur atau tata cara pendaftaran yang berada pada Peraturan Pemerintah Nomor. 51 tahun 2007 tentang Indikasi Geografis.

\section{Pendaftaran Indikasi Geografis untuk melindungi produk-produk masyarakat lo- kal}

Dengan berlakunya PP Nomor 51 Tahun 2007 tentang IG maka pendaftaran atas IG untuk melindungi produk-produk lokal dapat dilaksanakan sesegera mungkun, namun sampai saat inipun masih kurangnya masyarakat lokal melakukan pendaftaran.

Yang menjadi persoalan selama ini berkenaan dengan sistem pendaftaran IG sebagaimana telah tercantum diatas, maka pada ayat (3) dari pasal 6 PP Nomor 51 Thn 2007 tentang IG, masih terdapat kesulitan bagi masyarakat lokal untuk melakukan pendaftaran, karena masyarakat lokal tidak mengetahui bagaimana melakukan penelusaran untuk menjelaskan uraian-uraian yang tertera pada buku persyaratan tersebut. Penelusaran uraian membutuhkan waktu yang cukup panjang mengakibatkan masyarakat belum siap untuk melakukan pendaftaran.

Apabila masyarakat lokal telah memenuhi persyaratan sebagaimana pada buku persyaratan dan telah mendaftarkannya maka Ditjen HKI Kementerian Hukum dan HAM RI akan menunjuk seorang petugasnya untuk melakukan penelitian langsung apakah produk yang diajukan yang didaftarkan telah memenuhi uraian sebagaimana yang terdapat pada buku persyaratan. Setelah melakukan penelitian dan penelusuran atas produk tersebut dan dinyatakan sesuai dengan buku persyaratan maka produk yang telah didaftarkan diakui sebagai produk milik masyarakat tersebut yang kemudian diproses untuk mendapatkan sertifikat IG.

Hal lain yang membuat masyarakat belum juga melakukan perndaftarannya, apabila dalam memproseskan pendaftaran yang kemudian adanya keberatan dari pihak lain maupun terjadi penolakan maka memakan waktu yang cukup lama untuk menyelesaikannya, kemudian sebagian masyarakat beranggapan bahwa proses HKI cukup berbelit-belit dan mahal

Berdasarkan beberapa informasi yang bersumber dari masyarakat menunjukkan bahwa produk-produk milik masyarakat lebih banyak didaftarkan secara perorangan atau secara individu berdasarkan UU Merek, baik yang dilakukan oleh orang yang berada didalam negeri yang mengelola poduk tersebut maupun yang dilakukan oleh pihak luar yang pengelolaannya didalam wilayah di Inonesia atas ijin pemerintah baik pusat maupun daerah, misalnya pada kopi Toraja karena persyaratan pendaftaran pada Merek lebih mudah sekalipun biaya pendaftarannya mahal sebab uraian pada merek tidak serumit uraian yang terdapat pada IG.

1. Tahap Pertama: Mengajukan Permohonan

Setiap asosiasi, produsen atau organisasi yang mewakili produk Indi-kasi Geografis dapat mengajukan permohonan dengan memenuhi persyaratan-persyaratan yaitu dengan melampirkan: 
1) Permohonan diajukan secara tertulis dalam bahasa Indonesia oleh Pemohon atau melalui Kuasanyadengan mengisi formulir dalam rangkap 3 (tiga) kepada Direktorat Jenderal;

2) Surat kuasa khusus, apabila Permohonan diajukan melalui Kuasa;

3) Bukti Pembayaran Biaya;

4) Buku Persyaratan yang terdiri atas:

a) Nama Indikasi-geografis dimohon-kan pendaftarannya;

b) Nama barang yang dilindungi oleh Indikasi-geografis;

c) Uraian mengenai karakteristik dan kualitas yang membedakan barang tertentu dengan barang lain yang memiliki kategori sama, dan men- jelaskan tentang hubungannya dengan daerah tempat barang ter- sebut dihasilkan;

d) Uraian mengenai lingkungan geografis serta faktor alam dan faktor manusia yang merupakan satu kesatuan dalam memberikan pengaruh terhadap kualitas atau karakteristik dari barang yang dihasilkan;

e) Uraian tentang batas -batas daerah dan/atau peta wilayah yang dicakup oleh Indikasi-geografis;

f) Uraian mengenai sejarah dan tradisi yang berhubungan dengan pe- makaian Indikasi-geografis untuk menandai barang yang dihasilkan didaerah tersebut, termasuk pengakuan dari masyarakat mengenai Indikasi geografis tersebut;

g) Uraian yang menjelaskan tentang proses produksi, proses pengolah- an, dan proses pembuatan yang di-gunakan sehingga memungkinkan setiap produsen di daerah tersebut untuk memproduksi, mengolah, atau membuat barang terkait;

h) Uraian mengenai metode yang digunakan untuk menguji kualitas barang yang dihasilkan; dan

i) Label yang digunakan pada barang dan memuat Indikasi-geografis.

j) Uraian tentang batas-batas daerah dan/atau peta wilayah yang dicakup oleh Indikasi-geografis yang mendapat rekomendasi dari instansi yang berwenang.

2. Tahap Kedua: Pemeriksaan Administratif

Pada tahap ini pemeriksa melakukan pemeriksaan secara cermat dari per-mohonan untuk melihat apabila adanya kekurangan-kekurangan per-syaratan yang diajukan. Dalam hal adanya kekurangan Pemeriksa dapat mengkomunikasikan hal ini kepada pemohon untuk diperbaiki dalam tenggang waktu 3 (tiga) bulan dan apabila tidak dapat diperbaiki maka permohonan tersebut ditolak.

\section{Tahap Ketiga:Pemeriksaan Substansi}

Pada tahap ini permohonan diperiksa. Permohonan Indikasigeografis dengan tipe produk yang berbeda-beda, Tim Ahli yang terdiri dari para pemeriksa yang ahli pada bidangnya memeriksa isi dari pernyataan-pernyataan yang telah diajukan untuk memastikan kebenarannya dengan pengkoreksian, setelahdinyatakanmemadaimakaakan dikeluarkan Laporan Pemeriksaan yang usulannya akan disampaikan kepada Direktorat Jenderal. 
4. Tahap Keempat : Pengumuman

Dalam jangka waktu paling lama 10 (sepuluh) hari sejak tanggal disetujuinya Indikasi-geografis untuk didaftar maupun ditolak, Direktorat Jenderal mengumumkan keputusan tersebut dalam Berita Resmi Indikasi geografis selama 3 (tiga) bulan. Pengumuman akan memuat hal-hal antara lain: nomor Permohonan, nama lengkap dan alamat Pemohon, nama dan alamat Kuasanya, Tanggal Penerimaan, Indikasigeografis di- maksud, dan abstrak dari Buku Persyaratan.

\section{Tahap Ke Lima : Oposisi Pendaftaran.}

Setiap orang yang memperhatikan Berita Resmi Indikasi geografis dapat mengajukan oposisi dengan adanya Persetujuan Pendaftaran Indikasi Geografis yang tercantum pada Berita Resmi Indikasi Geografis. Oposisi diajukan dengan membuat keberatan disertai dengan alasan-alasannya dan pihak pendaftar/pemohon Indikasi geografis dapatmengajukan sanggahan atas keberatan tersebut.

\section{Tahap Ke Enam: Pendaftaran}

Terhadap Permohonan Indikasi Geo-grafis yang disetujui dan tidak ada oposisiatau sudah adanya keputusan final atas oposisi untuk tetap didaftar. Tanggal pendaftaran sama dengan tanggal ketika diajukan aplikasi. Direktorat Jenderal kemudian memberikan sertifikat Pendaftaran Indikasi Geografis, Sertifikat dapat diperbaiki apabila terjadi kekeliruan.

\section{Tahap Ketujuh: Pengawasan terhadap Pemakaian Indikasi-Geografis}

Pada Tahap ini Tim Ahli Indikasi-geografis mengorganisasikan dan memonitor pengawasan terhadap pemakaian In- dikasi-geografis di wilayah Republik Indonesia. Dalam hal ini berartibahwa Indikasi Geografis yang dipakai tetap sesuai sebagaimana buku persyaratan yang diajukan.

\section{Tahap Kedelapan : Banding}

Permohonan banding dapat diajukan kepada Komisi Banding Merek oleh Pemohon atau Kuasanya terhadap penolakan Permohonan dalam jangka waktu 3 (tiga Bulan) sejak putusan penolakan diterima dengan membayar biaya yang telah ditetapkan.

Berikut gambaran proses mekanisme membutuhkan waktu yang cukup lama bagi masyarakat untuk menunggu terbitan suatu sertifikat yang akan digunakan sebagai landasan hukum untuk melindungi produk lokalnya atas IG. Lamanya mekanisme tersebut mengakibatkan masyarakat belum dan atau kurang berminat melakukan pendaftaran atas IG, sebab pendaftaran tersebut harus memenuhi kriteria dari uraian buku persyaratan sebagaimana yang tertuang dalam pasal 6 ayat (3) dan (4) peraturan pemerintah Nomor 51 tentang IG.

Menurut Didit Karyadi ${ }^{17}$ apabila masyarakat lokal telah melakukan pendaftaran atas IG dengan memenuhi kriteria-kriteria yang ada khususnya yang disesuaikan buku persyaratan, maka Ditjen HKI khususnya bagian IG akan melakukan penelitian lapangan ke lokasi untuk menguji produk yang didaftarkan tersebut mempunyai kualitas, karakteristik, reputasi dan sesuai dengan yang didaftarakan tersebut. Mnurutnya juga mekanisme seperti ini merupakan suatu persoalan yang cukup panjang dan lama yang harus ditempuh oleh masyarakat yang kemudian masyarakat belum siap melakukan pendaftaran tersebut.

${ }^{17}$ Wawancara langsung dengan Didit Karyadi, Kapala Bagian Pemeriksaan Merek Pada Dirjen HKI Kemeneterian Hukum dan HAM. RI.pada tanggal 18 Mei 2010. 
MEKANISME PENDAFTARAN INDIKASI GEOGRAFIS

PADA PP NOMOR 51 TAHUN 2007 TENTANG INDIKASI GEOGRAFIS

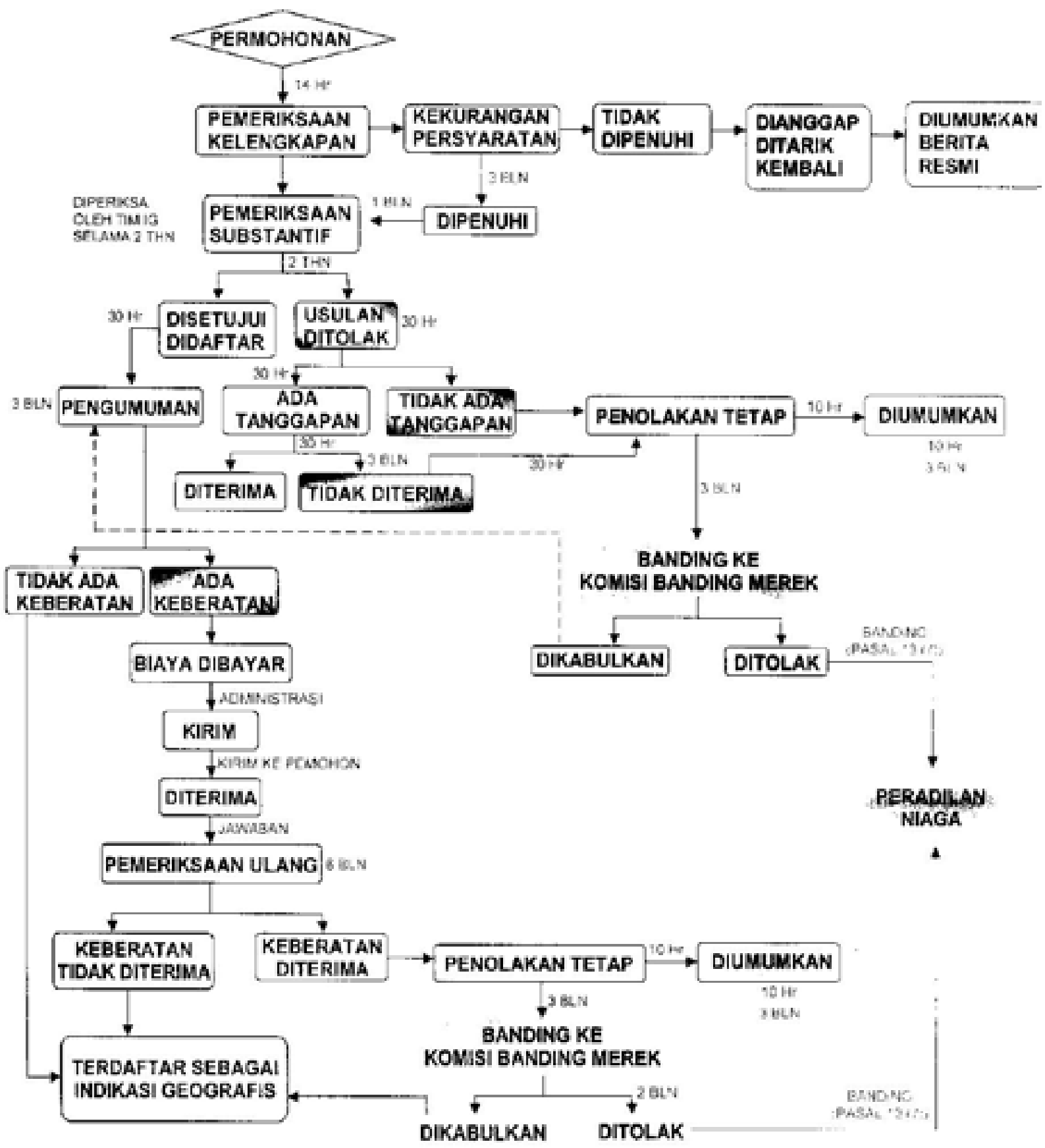

\section{KESIMPULAN}

Indikasi Geografis perlu mendapat perlindungan hukum sebab banyaknya produkproduk masyarakat lokal yang ada diberbagai daerah sampai saat ini masih banyak yang belum dilindungi karena belum melakukan pendaftaran. Selama ini perlindungan atas Indikasi geografis terhadap produk-produk lokal dapat dilakukan dengan memenuhi persyaratan dan Tata Cara Permohonan Indikasi Geografis berdasarkan Peraturan Pemerintah Nomor 51 Tahun 2007. Apabila ditelusuri lebih jauh mengapa masyarakat belum melakukan pendaftaran indikasi geografis atas produk-produk lokal hal ini 
karena : a) masyarakat belum mengetahui akan ketentuan IG yang melekat pada UU Merek, sebab selama ini merek yang lebih dominan karena pendaftarannya secara perorangan; $b$ ) masyarakat beranggap produk-produk lokal hanya dapat dipergunakan sekali pemakaian artinya produk-produk tersebut tidak perlu didaftarkan apabila terjadi penjualan maka dianggap selesai ; c) masyarakat khususnya pelaku usaha lebih senang mendaftarkan produkproduk lokal yang dikelola dengan sistem merek, karena banyak memberikan manfaat dan dapat mencapai keuntungan secara perorangan maupun dalam bisnisnya. Pemerintah pusat maupun daerah harusnya merupakan perpanjangan tangan harus membantu masyarakat dalam melakukan pendaftaran atas produk-produk lokal yang berindikasi geografis sebab hal ini dapat memberikan kesejahteraan bagi masyarakat lokal diwilayah mereka. Adanya perlindungan hukum dimaksudkan agar pemilik hak dapat menggunakan atau mengekploitasi kekayaan yang ada didaerah dengan aman, yang pada gilirannya, rasa aman itu kemudian menciptakan iklim atau suasana perekonomian untuk mensejahterakan rakyatnya di daerah itu sendiri.

\section{DAFTAR PUSTAKA}

Abdul Bari Azed, Kepentingan Negara Berkembang atas Indikasi Geografis, Sumberdaya Genetik dan Pengetahuan Tradisional, Lembaga Pengkajian Hukum Universitas Indonesia Kerjasama dengan Ditjen HKI, Perpustakaan Nasional RI.

E Utrecht, Pengantar Dalam Hukum Indonesia, Djakarta. Balai Buku “Ichtisar”, Cetakan keempat.

Emawati Yunus, Suara Merdeka, 2000.

Didit Karyadi, Kapala Bagian Pemeriksaan Merek Pada Dirjen HKI Kemenkumham. RI.

Delphine Marie-Vivvien."Geographical Indication and International Legal Framework". Dalam Liputsan Khusus, Media HKI. Vol.II/No.1/April 2004.

Mahmud MD. Konsepsi dan Implementasi Negara Hukum Kita, dalam Orasi Ilmiah Siding Terbuka STIH IBLAM, Pasca Sarjana Magister Ilmu Hukum Thn 2003.

Hoebel.(1968). The Law of Primitive Man, Atheneum, New York.

L Friedman.(1977). The Legal System: A Social Science Perspective. New York: Russel Sage Foundation.

Muchtar Kusumaatmadja.(1976). Hukum, Masyarakat dan Pembinaan Hukum Nasional. Jakarta: Bina Cipta.

O’Conner.(2004). Sue Generis Protection of Geographical Indication. Fall: Darake Jurnal of Agricultural Law.

Rahmi Jenet.(2007).Hak Kekayaan Intelektual, Penyalagunaan Hak Ekseklusif. Surabaya: Airlangga University Press.

Saki Septioano salah satu Kasubbid Perlindungan IG pada Dirjen HKI Kemenkumham RI.

Yehezkel Dror.(1981). Ventures and Policy Scince Conceptsand Application. New York: Elsevier.

128 Nurohma | Perlindungan Indikasi Geografis Berdasarkan Peraturan Pemerintah ... 